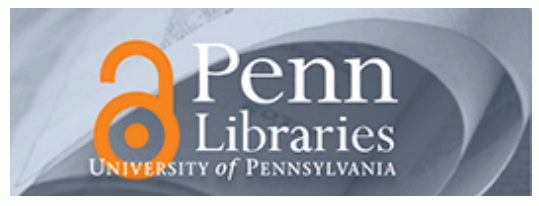

University of Pennsylvania

ScholarlyCommons

Management Papers

Wharton Faculty Research

2-2012

\title{
Work Motivation: Directing, Energizing, and Maintaining Effort (and Research)
}

Adam M. Grant

University of Pennsylvania

Jihae Shin

University of Pennsylvania

Follow this and additional works at: https://repository.upenn.edu/mgmt_papers

Part of the Management Sciences and Quantitative Methods Commons

\section{Recommended Citation (OVERRIDE)}

Grant, A.M. \& Shin, J. (2012). Work Motivation: Directing, Energizing, and Maintaining Effort (and Research). In R.M. Ryan (Ed.), The Oxford Handbook of Human Motivation. New York: Oxford University Press.

This paper is posted at ScholarlyCommons. https://repository.upenn.edu/mgmt_papers/250

For more information, please contact repository@pobox.upenn.edu. 


\title{
Work Motivation: Directing, Energizing, and Maintaining Effort (and Research)
}

\begin{abstract}
This chapter provides an overview of contemporary research on work motivation. We start by identifying the central premises, controversies, and unanswered questions related to five core theoretical perspectives on work motivation: expectancy theory, equity theory, goal-setting theory, job design, and self-determination theory. We then discuss four current topics and new directions: collective motivation and organizing, temporal dynamics, creativity, and the effects of rewards.
\end{abstract}

\section{Keywords}

work motivation, expectancy theory, equity theory, goal setting, job design, self-determination theory, organizing, creativity, rewards

Disciplines

Management Sciences and Quantitative Methods 


\title{
Oxford Handbooks Online
}

\section{Work Motivation: Directing, Energizing, and Maintaining Effort (and Research)}

Adam M. Grant and Jihae Shin

The Oxford Handbook of Human Motivation

Edited by Richard M. Ryan

Print Publication Date: Feb 2012 Subject: Psychology, Social Psychology

Online Publication Date: Sep 2012 DOI: 10.1093/oxfordhb/9780195399820.013.0028

\begin{abstract}
Keywords
This chapter provides an overview of contemporary research on work motivation. We start by identifying the central premises, controversies, and unanswered questions related to five core theoretical perspectives on work motivation: expectancy theory, equity theory, goal-setting theory, job design, and self-determination theory. We then discuss four current topics and new directions: collective motivation and organizing, temporal dynamics, creativity, and the effects of rewards.
\end{abstract}

Keywords: work motivation, expectancy theory, equity theory, goal setting, job design, self-determination theory, organizing, creativity, rewards 


\section{Introduction}

Work motivation is an important phenomenon for both scholars and practitioners to understand. It helps to explain what drove Thomas Edison to invent the first light bulb, Florence Nightingale to improve nursing practices, Nelson Mandela to become the president of South Africa, Benjamin Franklin to create fire and police departments, Maya Angelou to write poetry, and Michelangelo to paint the Sistine Chapel. Knowledge of work motivation also has the potential to shed light on major collective accomplishments such as discovering flight, landing on the moon, curing river blindness, and inventing the telephone and the computer. Underlying all of these accomplishments is a desire to take action.

Work motivation is described as the psychological processes that direct, energize, and maintain action toward a job, task, role, or project (Campbell \& Pritchard,

1976; Kanfer, 1990). Our chapter is not designed to be exhaustive; comprehensive reviews of work motivation theory and research are available in other outlets (e.g., Ambrose \& Kulik,

Diefendorff \& Chandler, $\quad$ 2010; Kanfer, Chen, \& Pritchard, $\quad$ 2008; Latham \& Pinder, $\quad$ 2005;

Mitchell \& Daniels, 2003). Rather, our goal is to provide an overview of core theoretical perspectives, key studies, important controversies and unanswered questions, as well as call attention to hot topics and new directions for work motivation theory and research. We start by discussing five core theoretical perspectives on work motivation: expectancy theory, equity theory, goal-setting theory, job design, and self-determination theory. We then turn our attention to four new directions and underexplored topics for work motivation research: group motivation and organizing, motivation over time, motivation and creativity, and the effects of rewards.

\section{Core Theoretical Perspectives on Work Motivation}

Scholars have distinguished between two principal types of work motivation theories: endogenous process theories and exogenous cause theories (Katzell \& Thompson, 1990). Endogenous process theories focus primarily on the psychological mechanisms that explain motivation inside employees' heads, while exogenous cause theories focus primarily on contextual influences on work motivation that can be changed and altered. We begin with a consideration of two key endogenous process (p. 506) theories: expectancy theory and equity theory. Next, we cover two central exogenous cause theories: goal setting and job design. Finally, we examine self-determination theory as a hybrid perspective that places equivalent emphasis on endogenous processes and exogenous causes. 


\section{Expectancy Theory}

According to expectancy theory, employees choose to invest effort in courses of action by weighing their relative utilities - that is, their probabilities of achieving desired outcomes (Vroom, 1964). Effort is a function of three beliefs: expectancy (effort will lead to performance), instrumentality (performance will lead to outcomes), and valence (these outcomes are important or valued). These beliefs are thought to interactively influence effort, such that if any one of the beliefs is missing, the course of action will not be selected (Porter \& Lawler, 1968). Without expectancy beliefs, employees feel that effort is futile; without instrumentality and valence beliefs, employees question whether performance is worth the effort. Critically, expectancy theory is designed to account for the within-person decisions that employees make about whether, where, and how to invest their time and energy, rather than for differences in effort between employees.

Expectancy theory has been tested in many studies, but it is more often used as an organizing framework for generating and testing context-specific hypotheses. For example, researchers have applied expectancy theory to guide the development of models to explain variations in DUI arrests among police officers (Mastrofski, Ritti, \& Snipes, 1994), efforts by middle managers to champion issues for senior executives to pursue (Ashford, Rothbard, Piderit, \& Dutton, 1998), home runs hit by major league baseball players (Harder, 1991), and strategic decisions in competitive markets (Chen \& Miller, 1994). In a meta-analysis of 77 studies, Van Eerde and Thierry (1996) found that expectancy, instrumentality, and valence beliefs were better predictors of psychological indicators of motivation (intentions and preferences) than of behavioral indicators (performance, effort, and choices), which may be an artifact of common method and source biases. Supporting one fundamental tenet of the theory, they found that expectancy, instrumentality, and valence beliefs were more accurate predictors of withinperson than between-person differences in criteria. However, they found that the multiplicative model explained little variance over and above the additive model. This may be an artifact of the low reliability of multiplicative measures. Moreover, the metaanalysis provided little information about causality, as most studies have been correlational rather than experimental. Nevertheless, the overall results suggest that expectancy, instrumentality, and valence beliefs do take a valuable step toward explaining variance in work motivation.

Research on expectancy theory has generated several controversies and unanswered questions. In light of evidence that expectancy, instrumentality, and valence beliefs leave considerable variance in motivation unexplained (Van Eerde \& Thierry, 1996), it is critical to understand other forces that influence motivation. The theory of planned behavior (Ajzen, 1991) takes a productive step in this direction. According to this theory, planned actions are directly caused by intentions as micromediators of the belief-behavior relationship. Intentions are in turn a function of perceived behavioral control over the behavior, attitudes toward the behavior, and subjective norms about the behavior. 


\section{Work Motivation: Directing, Energizing, and Maintaining Effort (and Research)}

Comparing the planned behavior and expectancy theories reveals both similarities and useful distinctions. Perceived behavioral control, which is akin to self-efficacy (Bandura, 1977) ${ }^{2}$, corresponds to expectancy beliefs, as both describe employees' judgments about whether they are capable of performing if they expend effort. Attitudes, which capture the extent to which an employee evaluates the behavior favorably, appear to overlap with both instrumentality and valence beliefs, which—in tandem—connote that the behavior will lead to favorable outcomes. Moving beyond expectancy theory, the theory of planned behavior adds subjective norms, or social expectations and pressure to engage in the behavior. The underlying premise is that employees derive utility not only from personal outcomes but also from social rewards that convey approval, respect, and community and social punishments that convey disapproval, disrespect, and alienation. In a meta-analysis of 185 studies, Armitage and Conner (2001) found that perceived behavioral control, attitudes, subjective norms, and intentions combined to explain $27 \%$ of the variance in behaviors (31\% when self-reported and $21 \%$ when objectively measured or observerrated) and $39 \%$ of the variance in intentions. Both subjective norms and intentions explained unique variance in behaviors after accounting for perceived behavioral control and attitudes, which highlights the potential value of including these two psychological constructs to expand the predictive validity of expectancy theory.

(p. 507) A second limitation of expectancy theory is that it is often viewed as overly calculative (Ashford et al., $\quad$ 1998; Mitchell \& Daniels, 2003; Staw, 1984). Although the theory is reasonably effective in predicting motivation and behavior, it creates a caricature of how employees actually make decisions and experience motivation. With the possible exceptions of mathematicians, engineers, financial analysts, and economists, rarely have we seen an employee sit down and calculate the probabilities of effort leading to performance and performance leading to outcomes, and the utility of these outcomes. It would be even more uncommon for an employee to perform these calculations for multiple possible courses of action. With this limitation in mind, scholars have begun to incorporate "hot" affective components into expectancy theory (Seo, Barrett, \& Bartunek, 2004). For example, Erez and Isen (2002) demonstrated that positive affect can increase expectancy, instrumentality, and valence beliefs, but only under task conditions that are supportive of these beliefs (e.g., working on a task in which performance is based on effort rather than chance). This research takes a step toward capturing the real-time, affect-laden processes through which expectancy, instrumentality, and valence judgments are made (see also Seo et al., 2004).

Expectancy theory has also been criticized for failing to specify the nature and sources of variations in employees' beliefs and judgments. Employees can attach valence not only to outcomes of performance but also to effort and performance as ends in and of themselves. For example, Eisenberger's (1992) theory of learned industriousness explains how, when employees are rewarded for effort over time, hard work can take on secondary reward properties, such that employees naturally enjoy the very experience of expending effort. In addition, employees tend to view performance as a reward in and of itself when 


\section{Work Motivation: Directing, Energizing, and Maintaining Effort (and Research)}

they are growth oriented (Hackman \& Oldham,

1976), conscientious (Grant, 2008b), and achievement motivated (McClelland, 1961), suggesting that they will place valence on performance even when there are no external outcomes attached to it.

Finally, expectancy theory falls short of explaining how employees update and change their beliefs over time (Mitchell \& Biglan, 1971). For example, valence beliefs can change as employees realize that their actual satisfaction with an outcome is different (e.g., lower or higher) than the satisfaction that they anticipated (e.g., Wilson \& Gilbert, 2005). As an endogenous process theory (Katzell \& Thompson, 1990), the focus of expectancy theory has been on identifying the key psychological forces that guide decisions about effort and understanding their consequences, rather than specifying their causes or fluctuations. Despite these limitations, expectancy theory is appealing in its theoretical parsimony and its applications to diagnosing and resolving motivational problems in organizations, and thus it remains a popular and widely used theory.

\section{Equity Theory}

Equity theory (Adams, 1963, 1965) takes a step toward placing motivation more squarely in a social context. The central assumption of equity theory is that employees are motivated when their inputs (e.g., effort, knowledge, skill, loyalty) are matched by outcomes (e.g., pay, bonuses, benefits, recognition), which creates a sense of equity or fairness. When outcomes do not match inputs, the resulting perceptions of inequity lead to distress, which motivates employees to take action to reduce it. When employees feel underrewarded, they may restore perceived equity by reducing their inputs (slacking off), attempting to reduce others' inputs (convincing coworkers to do less work or sabotaging their efforts to be productive), seeking to increase their outcomes (asking for a raise or vacation time), or aiming to decrease coworkers' outcomes (asking them to take a pay cut or lobbying a boss to standardize salaries). When employees feel overrewarded, they may restore perceived equity by increasing their inputs (working harder) or reducing their outcomes (requesting a pay cut or redistributing their salaries to coworkers).

How do employees make judgments of equity? To evaluate input-outcome ratios, employees can make a range of comparisons (Adams, 1963, 1965). One set of comparisons is between outcomes and inputs such as effort (the time and energy that I invested), ability (my knowledge, skills, and talents), and seniority (my tenure and loyalty). Another set of comparisons is of the input-outcome ratios to other input-outcome ratios, including my own past input-outcome ratios (what I have received elsewhere or before, relative to my contributions) and others' input-outcome ratios (are mine appropriate in light of the ratios of similar others?). This last comparison, the social comparison, is often viewed as the central theoretical insight offered by equity theory (Weick, 1966): Even when employees receive outcomes that match their inputs, their motivation can suffer when they perceive others as maintaining more favorable inputoutcome ratios. For example, studies have shown that higher pay dispersion-the disparity in compensation between the highest-paid (p. 508) and lowest-paid employees in 


\section{Work Motivation: Directing, Energizing, and Maintaining Effort (and Research)}

an organization—predicts greater manager and employee turnover (Bloom \& Michel, 2002), lower job satisfaction, productivity, and collaboration (Pfeffer \& Langton,

and in major league baseball teams, fewer runs scored, more runs given up by pitchers, and more losses (Bloom, 1999).

Equity theory assumes that both underrewarding employees and overrewarding employees can be detrimental to motivation. Although research has consistently shown negative motivational and behavioral effects of underreward inequity, evidence reveals mixed results about the consequences of overreward inequity: Some employees appear to decrease their motivation, others increase it, and still others show no significant changes (Ambrose \& Kulik, 1999). One approach to resolving these conflicting findings has involved understanding individual differences in equity sensitivity. Huseman, Hatfield, and Miles (1987) proposed that employees can be classified into one of three categories of equity preferences: benevolent (preferring a lower outcome/input ratio than comparison others), equity sensitive (preferring an equal outcome/input ratio to comparison others), and entitled (preferring a higher outcome/input ratio than comparison others). Accordingly, overreward inequity leads to higher motivation among benevolent and equity-sensitive employees than entitled employees (Miles, Hatfield, \& Huseman, 1989). Benevolent and equity-sensitive employees are willing to work to restore fairness, whereas entitled employees may be quite content with receiving more than they contribute.

A key controversy in work motivation research concerns competing predictions between equity and expectancy theories in situations characterized by the combination of perceived underreward inequity and high instrumentality beliefs (Harder, According to equity theory, when instrumentality is high, employees who feel underrewarded will be distressed by perceived inequity and may reduce their effort to create a more appropriate balance between their inputs and outcomes. On the other hand, expectancy theory predicts that when instrumentality is high, employees who feel underrewarded will be motivated to achieve higher performance, as they are confident that this will result in the rewards they feel they deserve. Harder (1991) provided a theoretical and empirical resolution of this controversy in a study of major league baseball free agents. He found that under low instrumentality, negative performance effects of inequity were visible, but under high instrumentality, individuals maintained their performance: "individuals faced with inequitable underreward will choose the avenue of decreased performance to the extent that it does not affect future rewards. If decreasing performance will adversely affect future rewards, then alternative avenues for restoring equity will be undertaken" (Harder, 1991 , pp. 463-464).

Another issue facing equity theory concerns how organizations and employees handle inconsistencies in equity that emerge between different types of comparisons. For example, when pay dispersion is high, star performers making self-comparisons perceive high equity, but average and low performers making social comparisons may perceive low equity. In general, research suggests that in some circumstances, the costs of perceived inequity among the latter group can outweigh the benefits of perceived equity among the 


\section{Work Motivation: Directing, Energizing, and Maintaining Effort (and Research)}

former group (Bloom, 1999; Messersmith, Guthrie, Ji, \& Lee, 2011; Siegel \& Hambrick,

2005). However, this research has yet to identify conditions under which organizations can create favorable perceptions of equity for different groups of employees. One practical solution, pay secrecy, appears to be a mixed bag, as employees often view it as a signal of inequity and resist by going out of their way to publicize their salaries (Colella, Paetzold, Zardkoohi, \& Wesson, 2007).

\section{Goal-Setting Theory}

One criticism of both expectancy and equity theories is that they focus primarily on psychological processes involved in work motivation, providing little explicit theory and guidance for explaining the role of contextual forces (Katzell \& Thompson, 1990). Goalsetting theory overcomes these limitations by focusing on the motivational effects of goals, or targets for action. Extensive research has shown that difficult, specific goals motivate high performance by focusing attention, increasing effort and persistence, and encouraging the development of novel task strategies (Locke \& Latham, 1990). For instance, classic studies showed that setting specific, difficult goals—relative to "do your best," easy, or no goals - for 36 truck drivers transporting logs led them to increase from $60 \%$ to $90 \%$ of legal allowable weight, saving the company approximately $\$ 250,000$ in less than a year (for a review, see Locke \& Latham, 2002). In another study, Latham and Saari (1982) gave 39 truck drivers the goal of enhancing the number of daily trips that they took to the mill, which yielded $15 \%$ average daily increases in trips and saved the company approximately $\$ 2.7$ million in less than 4 months.

(p. 509) Difficult, specific goals are most likely to produce these effects when employees are committed to them, when they receive feedback, and when tasks are simple rather than complex. Without commitment, employees question whether it is worthwhile to work toward difficult goals. Without feedback, employees cannot gauge their progress and adjust effort, persistence, and task strategies accordingly. When tasks are simple, effort is a key determinant of performance, but when tasks are complex, ability and task strategies become more influential, reducing the performance effects of goal setting as a motivational technique (Locke \& Latham, 2002).

At first glance, the principle of difficult goals motivating higher performance than easy goals appears to conflict with expectancy theory. From an expectancy theory standpoint, easy goals yield greater effort-to-performance expectancy beliefs, and thus greater motivation and performance, than difficult goals. Researchers have resolved this tension by showing that when goal difficulty is held constant, higher expectancy beliefs are associated with higher performance, but when goal difficulty varies, more difficult goals are linked with higher performance, as the attention, effort, persistence, and task strategy benefits of difficult goals appear to outweigh the costs of lower expectancy beliefs (Locke, Motowidlo, \& Bobko, 1986). Furthermore, expectancy beliefs moderate the effects of goal difficulty on performance, such that setting difficult goals only 


\section{Work Motivation: Directing, Energizing, and Maintaining Effort (and Research)}

motivates employees to take action if they believe such action has the potential to achieve the goals (Locke \& Latham, 2002).

As goal-setting theory gained prominence, scholars began to raise concerns about managers using goals as manipulative tools, and they expressed growing interest in understanding the motivational effects of goals that were self-set by employees. This yielded a major controversy about whether participation in goal setting increases motivation and performance. Holding goal difficulty constant, studies by Latham and colleagues showed null effects of participation, whereas studies by Erez and colleagues identified significant benefits. The authors collaborated, with Locke as a mediator (not a moderator), to jointly design experiments to resolve the dispute. They discovered that the effects of participation in goal setting depend on goal commitment. When the purpose of the goals is clear, participation offers little benefit, but when the purpose is unclear, allowing employees to participate serves the function of increasing goal commitment and thereby motivates higher performance (Latham, Erez, \& Locke, 1988). Subsequent studies suggested that participation may achieve these benefits not only through motivational mechanisms but also through cognitive mechanisms of enabling employees to share information about task strategies and building self-efficacy (Locke \& Latham, 2002). Moreover, employees who have high self-efficacy with respect to assigned goals tend to set higher goals, experience greater goal commitment, choose better task strategies, and maintain goal pursuit in the face of negative feedback (Locke \& Latham, 2002).

Of course, if employees' goals are not aligned with organizational goals, goal setting can reduce rather than increase performance (Locke \& Latham, 2002). This raises important ethical issues, as employees can take unethical or illegal shortcuts to achieve goals. For example, Schweitzer, Ordoñez, and Douma (2004) conducted a laboratory experiment showing that participants were more likely to cheat by overstating their productivity when they had unmet goals than when they were simply asked to do their best. These effects were observed for goals with and without monetary incentives, and they were particularly pronounced when participants narrowly missed goal accomplishment (Schweitzer et al., 2004). A heated debate has ensued about whether goal-setting theory adequately addresses and accounts for these and other risks of goal setting, such as tunnel vision, stress, reduced learning and intrinsic motivation, and excessive risk taking and competition (Latham \& Locke, 2009; Locke \& Latham, 2009; Ordoñez, Schweitzer, Galinsky, \& Bazerman, 2009a， 2009b). We are sympathetic to the arguments of both sides. On one hand, goal-setting theorists have acknowledged many of these risks, and demonstrating that goals can increase unethical behavior is consistent with a premise of goal-setting theory that when employees are committed to goals, they will be motivated to discover and create task strategies for achieving them (Locke \& Latham, all, unethical behavior is a task strategy. On the other hand, although much is known about the motivation and performance effects of goal setting, substantially less theory and research has addressed the conditions under which goals are more versus less likely 


\section{Work Motivation: Directing, Energizing, and Maintaining Effort (and Research)}

to encourage unethical behavior and other unintended consequences (e.g., Barsky,

This represents an important direction for future research: Scholars should systematically build and test theories about the factors that amplify and mitigate the negative effects of goal setting.

\section{(p. 510) Job Design}

Goals are one important contextual influence on motivation, but how employees' jobs are structured also has a substantial impact on their motivation (for reviews, see Fried, Levi, \& Laurence, 2008; Grant \& Parker, 2009; Morgeson \& Humphrey, 2008; Oldham \& Hackman, 2010; Parker \& Ohly, 2008). Classic research on job design focused on the principle of job enrichment, which refers to altering the structural characteristics of employees' tasks to increase their motivating potential (Herzberg, 1959). The dominant approach to job enrichment is based on the Job Characteristics Model (Hackman \& Oldham, 1976, 1980), which proposes that motivation, satisfaction, performance quality, and withdrawal behaviors such as absenteeism and turnover are a function of three critical psychological states: experienced meaningfulness, responsibility for outcomes, and knowledge of results. Experienced meaningfulness is thought to be determined by three core job characteristics: skill variety (being challenged to use a variety of one's capabilities), task identity (completing a whole, identifiable piece of work from start to finish), and task significance (having an impact on other people inside or outside the organization). Experienced responsibility is thought to be shaped by the job characteristic of autonomy (freedom and discretion about when and how to complete the work) and experienced knowledge of results by the job characteristic of feedback (information from completing the work itself about one's progress and effectiveness). Thus, from a motivational standpoint, well-designed jobs are high in at least one of the dimensions of skill variety, task identity, and task significance, as well as in autonomy and feedback. These effects are moderated by individual differences in growth need strength, such that employees who value learning and development should be more responsive to both the enriched job characteristics and the critical psychological states, as well as by knowledge, skill, and satisfaction with the work context.

Field experiments and meta-analytic reviews have shown that as a whole, these job characteristics have good explanatory power for work motivation (Fried \& Ferris, Griffin, 1983). At the same time, the model has been critiqued and expanded on a number of grounds to include curvilinear effects of jobs that are "too" enriched (Xie \& Johns, 1995), consider how job perceptions are shaped by social information as well as objective task structures (Salancik \& Pfeffer, 1978; Zalesny \& Ford, 1990), account for variations between the different tasks that employees perform (Wong \& Campion, 1991) and workday schedules (Elsbach \& Hargadon, 2006), include knowledge and learning as well as motivational mechanisms for explaining job design effects (Parker, Wall, \& Jackson, 1997; Parker, Wall, \& Cordery, 2001), and examine how motivational approaches to job design from organizational psychology may involve tradeoffs with respect to mechanistic 


\section{Work Motivation: Directing, Energizing, and Maintaining Effort (and Research)}

approaches from industrial engineering, perceptual-motor approaches from human factors and cognitive psychology, and biological approaches from medicine (Campion \& McClelland, 1993; Morgeson \& Campion, 2002).

From a motivational standpoint, one critique of the Job Characteristics Model is that it focused on the enrichment of assigned tasks, overlooking the important role that interpersonal relationships play in motivation (for a review, see Grant \& Parker, 2009). Although early research included relational characteristics of jobs such as interactions with others and friendship opportunities (Hackman \& Lawler, 1971 ; Trist \& Bamforth,

1951; Turner \& Lawrence, 1965), they fell out of favor as Hackman and Oldham (1976) sought to focus squarely on the task characteristics that composed jobs. Recent research has examined the motivational effects of redesigning jobs to connect employees to their impact on the beneficiaries of their work - the clients, customers, patients, and other who are affected by their efforts (Grant, 2007). Studies have shown, for example, that when employees even have a short interaction with an end user of their work, they come to perceive their actions as having a greater impact and as more socially valued, and feel more committed to their end users in general, which motivates them to work harder and achieve higher performance and productivity (Grant, $\quad 2008$ b; Grant et al., 2007). As will be discussed in more detail later, this opens up the opportunity to understand how jobs can be designed not only to enhance intrinsic motivation but also to foster prosocial motivation - the desire to protect and promote the well-being of others (Grant,

2007).

Similar to the growing attention to self-set as opposed to manager-set goals, scholars have observed that managers are not the only architects of jobs; employees also take initiative to proactively alter the characteristics of their own jobs (for a review, see Grant \& Parker, 2009). Scholars have developed conceptual frameworks to explain the factors that motivate employees to adjust their roles (Nicholson, 1984) and craft or modify their jobs (Wrzesniewski \& Dutton, 2001). Recent research has revealed how employees take initiative to craft their jobs in pursuit $\quad$ (p. 511) of "unanswered callings" (Berg, Grant, \& Johnson, 2010), craft their jobs not only in isolation but also in collaboration (Leana, Appelbaum, \& Shevchuk, 2009), and experience and respond to challenges encountered in job crafting (Berg, Wrzesniewski, \& Dutton, 2010). Research has also explored how managers and employees work together to negotiate "idiosyncratic deals" about the motivational characteristics of jobs (Hornung, Rousseau, Glaser, Angerer, \& Weigl, Rousseau, Ho, \& Greenberg, 2006).

\section{Self-Determination Theory}

Scholars have long viewed intrinsic motivation - a desire to act based on interest and enjoyment of the work itself-as a key influence on work motivation, especially in the literatures on job design (Hackman \& Oldham, 1980) and creativity (Amabile \& Mueller, 2007; George, 2007; Shalley, Zhou, \& Oldham, 2004). Self-determination theory has begun to play a central role in expanding our understanding of intrinsic motivation and informing work motivation research more generally (for a review, see Gagné \& Deci, 


\section{Work Motivation: Directing, Energizing, and Maintaining Effort (and Research)}

2005). In work motivation research, self-determination theory has been particularly useful in resolving controversies about the conditions under which rewards and incentives have positive versus negative effects. According to self-determination theory, employees have three basic psychological needs: autonomy, competence, and relatedness (Ryan \& Deci, 2000). Autonomy refers to the feeling of choice and discretion, competence refers to feeling capable and efficacious, and relatedness refers to feelings of connectedness and belongingness with others.

Self-determination theorists propose that when these three psychological needs are fulfilled, employees are more likely to be intrinsically motivated and internalize external goals and objectives. Thus, when rewards and incentives are delivered in a manner that threatens feelings of autonomy, competence, and/or relatedness, employees will tend to react negatively. For example, explaining a reward system in a controlling rather than supportive manner can compromise employees' feelings of autonomy and relatedness (e.g., Deci, Connell, \& Ryan, 1989; Deci, Koestner, \& Ryan, 1999; see also Kramer,

On the other hand, as long as rewards and incentives are delivered in a manner that supports autonomy, competence, and relatedness, intrinsic motivation and internalization are more likely (e.g., Amabile, 1993). Other research suggests that additional features of compensation systems, such as variable versus fixed pay ratios and the number of people whose performance determines the reward (Gagné \& Forest, 2008), as well as the symbolic features of rewards - who distributes them, why, how, and to whom (Mickel \& Barron, 2008 ) -may affect self-determination and intrinsic motivation.

Self-determination theory also makes a valuable contribution to our understanding of work motivation by elaborating our understanding of extrinsic motivation. Rather than viewing extrinsic motivation as a unitary construct, Ryan and Deci (2000) proposed that extrinsic motivation is a matter of degree, varying along a continuum of autonomous regulation. They identified four different types of extrinsic motivation that employees experience as successively less controlled and more autonomous: external (based on outside reward and punishment contingencies), introjected (based on internal reward and punishment contingencies, such as guilt and self-esteem), identified (based on consistency with a personal value), and integrated (assimilated into one's system of values).

In the work domain, researchers have proposed that since external reward and incentive contingencies are virtually omnipresent, extrinsic and intrinsic motivations often coexist (Adler \& Chen, 2009; Staw, 1984). If this is true, employees might be expected to invest more time and energy in their work when they find it both intrinsically motivating and are able to identify or integrate it with their values (e.g., with prosocial values related to helping others). Consistent with this prediction, research has shown that intrinsic and prosocial motivations interact synergistically to predict higher levels of persistence, performance, and productivity among firefighters and fundraisers (Grant, as higher levels of creativity achieved by military security officers, water treatment employees, and participants in an experiment helping a local band make money (Grant \& Berry, 2011). Thus, intrinsic and identified-integrated motivations appear to be 


\section{Work Motivation: Directing, Energizing, and Maintaining Effort (and Research)}

particularly potent in combination. Other research has shown that autonomous motivations (intrinsic, integrated, identified) are more important for performance on complex rather than simple tasks, where autonomous motivations encourage exploration and persistence (for a review, see Gagné \& Deci, 2005).

Organizational scholars have also used self-determination theory to explain the motivational effects of transformational leadership_acting to inspire employees, model important values, and provide individualized consideration and intellectual stimulation. Bono and Judge (2003) conducted a field study and a laboratory experiment showing (p. 512) that transformational leaders encouraged employees to set autonomous rather than controlled goals, resulting in more positive attitudes and higher performance. Interestingly, their field study suggested that transformational leadership was associated positively with autonomous motivation but had no relationship with controlled motivation, while their lab experiment indicated that transformational leadership reduced controlled motivation more strongly than it increased autonomous motivation. Further research is still needed to explain this discrepancy, but the difference in the strength and content of rewards and incentives between the field and lab may be one key factor (Bono \& Judge, 2003).

Integrating job design and self-determination theories, we know much more about how intrinsic motivation is influenced by the structure than the content of employees' tasks. According to self-determination theory, feelings of autonomy, competence, and relatedness are important for intrinsic motivation. However, intrinsic motivation depends on enjoying the work itself, and some tasks are experienced by employees as "not in themselves interesting" (Gagné \& Deci, $\quad 2005$, p. 347). Thus, even when employees feel autonomous, competent, and connected to others, they may not experience intrinsic motivation in tasks that they do not find interesting or enjoyable. Currently, we lack a theoretical framework for specifying how particular task contents are more intrinsically interesting than others, and how different employees find different types of tasks interesting. It may be the case that one of the benefits of providing employees with autonomy is that it gives them the freedom and discretion to craft their jobs in ways that they find intrinsically motivating, but this has yet to be studied.

Finally, little research has explored the costs of intrinsic motivation in organizational settings. Research suggests that intrinsic motivation is less effective for performance in tasks that are simple or require considerable self-control and discipline (Gagné \& Deci, 2005; Koestner \& Losier, $\quad$ 2002). Scholars have begun to speculate that intrinsic motivation can distract attention away from organizational goals, or at the very least, is not necessarily aligned with them (Grant \& Berry, 2011; Osterloh \& Frey, addition, scholars have raised concerns that employees can be intrinsically motivated toward activities that are directly destructive or harmful, such as theft and sabotage (Osterloh \& Frey, 2000). As we noted for goal setting, more research is needed on the contingencies that affect whether and when intrinsic motivation is conducive to effective task performance and organizational citizenship behaviors (Gagné \& Deci,

2005). 


\section{Motivating New Directions}

Beyond these core theoretical perspectives, we see a range of contemporary issues and unanswered questions for work motivation research to address. In the following sections, we discuss four key current and new directions for motivation research: group motivation and organizing, motivation over time, motivation and creativity, and the effects of rewards.

\section{Group Motivation and Organizing}

Moving beyond the dominant emphasis on individual-level motivation, scholars have paid increasing attention to the role of motivation in work groups and teams. The most comprehensive perspective on this phenomenon is Chen and Kanfer's (2006) theoretical model integrating individual-level, group-level, and cross-level processes. They adopt a systems perspective to explain how, at both individual and team levels, motivational states affect goal generation and goal striving, and thus influence performance. They propose that individual motivational states are a function of employees' traits, work experience, the quality of relationships with their leaders, and individual feedback, while team motivational states are a function of leadership climate, group norms, work design, and team feedback. They further discuss how team and individual motivational processes reciprocally influence each other, as do individual and team performance. Recent research provides support for the general premises of the model. For example, Chen, Kanfer, DeShon, Mathieu, and Kozlowski (2009) demonstrated the cross-level influence of prior team performance on subsequent individual performance in two samples. They found that prior team performance influences self-efficacy by shaping prior individual performance and team efficacy, that team efficacy affects goal striving through selfefficacy and team action processes (e.g., helping and cooperation), and that these team action processes influence individual performance by shaping individual goal striving.

One exciting pathway for extending the Chen and Kanfer model involves examining the influence of motivation on organizing. Organizing refers to the processes through which individual members coordinate their actions to achieve collective goals (Weick,

it is among the most important yet neglected topics in all of organizational research (p. 513) (Heath \& Sitkin, 2001). Surprisingly little research has examined the impact of motivation on organizing. For example, there is a large literature on "high-reliability organizing" that examines how groups coordinate actions to achieve consistent, safe performance in uncertain, complex, consequential, high-risk contexts such as nuclear power plants, wildland firefighting, hospital emergency departments, and aircraft carriers (e.g., Hofmann \& Stetzer, $\quad$ 1998; Waller \& Roberts, $\quad$ 2003; Weick \& Roberts,

Traditional approaches to increasing reliability have focused on building collective capabilities for systems to manage unexpected events through the structuring of roles, routines, and norms (e.g., Bierly \& Spender, $\quad$ 1995; Bigley \& Roberts, $\quad 2001$; Vogus \& 
Welbourne, 2003; Weick, Sutcliffe, \& Obstfeld,

1999, 2005; Zohar \& Luria,

2003).

However, these collective capabilities are nearly useless if employees are not motivated

to put them into action. Researchers have yet to explore how individual and team

motivational processes affect the effective implementation of collective capabilities for

high reliability. Moreover, individual and team motivational processes may be important

catalysts of the decision to create and develop collective capabilities in the first place.

More generally, the impact of motivation on organizing has been neglected. One notable exception to this trend is the fascinating work by Adler and Chen (2009) on large-scale collaborative creativity. These authors focus on how social collectives are able to organize or coordinate efforts to develop and implement novel, useful solutions to problems, such as when hundreds or thousands of software developers collaborate to introduce a new computer program, aircraft engineers collaborate to develop a new design, and scientists create new pharmaceutical drugs. Building on self-determination theory, Adler and Chen (2009) present propositions to explain how large-scale collaborative creativity can be organized effectively through simultaneously activating intrinsic and identified motivations. We hope to see more research follow suit by examining how individual-level and team-level motivations influence the propensity and capacity to organize. Research on social motivations that are directed toward others, such as collectivistic work

motivation (Shamir, 1990, 1991), motivation to innovate (Amabile, 1988), and prosocial motivation (Grant, 2007，2008a; Grant \& Berry, 2011), may prove especially useful in drawing sharper theoretical and empirical links between motivation and the organizing of individual efforts into collective outcomes. In addition, recent developments in knowledge about proactive motivation - the desire to take anticipatory action to create change (for reviews, see Grant \& Parker, 2009; Parker, Bindl, \& Strauss, 2010 )—may help to explain the disproportionate influence of particular individual efforts on organizing. 


\section{Motivation Over Time}

In response to critiques that most motivation theory and research is overly static, scholars have begun to examine dynamic and temporal perspectives on motivation. One dynamic view adopts an adult development perspective to explain how motivations change across the life span (Kanfer \& Ackerman, 2004). These authors review research suggesting that aging is associated with declines in fluid intelligence (working memory, abstract reasoning, attention, and processing of novel information), but increases in crystallized intelligence (educational and experiential knowledge). They propose that as employees age, these changes increase the likelihood of enhancing effort to cope with jobs that place heavy demands on fluid intelligence, but this may compromise motivation and performance, as declining performance in the face of increased effort can reduce self-efficacy. In contrast, aging may be associated with more effective maintenance of motivation and performance in jobs that primarily require crystallized intelligence, as employees are able to sustain high performance in the absence of greater effort. As a result, from an instrumentality and valence standpoint, stronger rewards and incentives may be necessary to increase the performance of midlife employees (above current levels) in jobs requiring crystallized intelligence, compared to younger workers. Kanfer and Ackerman (2004) further propose that aging reduces the valence that employees place on effort and on increasing job performance, although the latter effect can be attenuated by performance standards that fit age-graded values, such as rising emphasis on social rather than technical competence.

Aging also has important implications for how employees grapple with death awareness and respond to mortality cues, and Grant and Wade-Benzoni (2009) proposed that these changes can have substantial effects on work motivation. These authors distinguished between two states of death awareness - the "hot" death anxiety typically studied by terror management theorists and the "cool" death reflection typically studied by generativity and posttraumatic growth theorists. They proposed that death anxiety is likely to motivate withdrawal (p. 514) behaviors from work, such as absenteeism, tardiness, and turnover, except when work serves as an escape from mortality cues. They argued that in contrast, death reflection has the potential to motivate generative work behaviors, such as helping, mentoring, and transitions to more prosocially focused or service-oriented occupations, especially for employees who view work as a calling. However, since empirical research has yet to test, challenge, complicate, and expand the propositions developed by Kanfer and Ackerman (2004) and Grant and Wade-Benzoni (2009), we encourage future studies on the impact of aging and death awareness on work motivation.

A different perspective on temporal changes in motivation appears in research on generational differences in work values. Twenge, Campbell, Hoffman, and Lance (2010) used a nationally representative sample of U.S. high school seniors in 1976, 1991, and 2006 to compare mean work values between the Baby Boomer, Generation X, and Millennial generations. A key feature of their analytic approach is that while cross- 


\section{Work Motivation: Directing, Energizing, and Maintaining Effort (and Research)}

sectional studies confound generational cohorts with age and life experience, longitudinal studies comparing participants at the same ages can isolate these factors. They discovered that on average, leisure values have increased with each new generation, corresponding with declines in work centrality. Extrinsic values, although highest among Generation X, remain higher among Millennials than Baby Boomers. Millennials appear to place less importance on social and intrinsic work values than Baby Boomers, and there were no significant differences in emphasis placed on altruistic work values.

There is a heavy debate about the practical significance of the effect sizes in this program of research (e.g., Trzesniewski \& Donnellan, 2010), and how they may be small in comparison to those of developmental and age effects (e.g., Roberts, Edmonds, \& Grijalva, 2010). However, because of its ability to isolate generational differences from age differences, this is the most rigorous study to date of generational differences in work values. The Twenge et al. (2010) findings raise interesting questions about whether, on average, employees from the Millennial generation will display stronger responses to motivational interventions focusing on leisure rewards (e.g., time off, paid vacations) and weaker responses to social rewards (e.g., making contacts and friendship opportunities) and intrinsic rewards (e.g., learning, interesting work, creative challenges).

These perspectives on life-span development and generational differences emphasize relatively macroscopic changes in motivation, but it is also important to understand more microscopic changes in motivation. Compared to research on the direction and intensity of effort, few theoretical models and empirical studies have focused on the maintenance or persistence of effort (e.g., Grant et al., 2007; Penner, Dovidio, Piliavin, \& Schroeder, 2005 ). Are the factors that sustain motivation different from those that initiate it -and if so, how, why, and when? Furthermore, little research has examined the factors that influence changes in the valence that employees place on different outcomes over time. For example, outside of changes in job designs and incentives, what leads employees to develop more intrinsic motivation toward a specific occupation, job, project, or task? As another example, researchers have established that employees vary in their orientations toward work as a job, a career, or a calling (Wrzesniewski, McCauley, Rozin, \& Schwartz, 1997; see also Bunderson \& Thompson, 2009). However, we know little about what leads employees to shift from viewing work as a job to a career or a career to a calling. We need a deeper understanding of the factors that shift employees' motivational orientations toward work over time.

\section{Motivation and Creativity}

Motivation is known to play a central role in creativity, or the production of novel and useful ideas, which is a topic of increasing interest and importance to organizations as the pace and uncertainty of work continue to accelerate. Amabile and colleagues have developed a componential theory of creativity that features intrinsic motivation prominently as an important influence on the creative process (Amabile,

Mueller, 2007). Intrinsic motivation is thought to enhance creativity by encouraging 
exploration and risk taking (Amabile, Hennessey, \& Grossman,

1986; Hennessey, Amabile,

\& Martinage, 1989), psychological engagement in work and in learning (Amabile, Hill, Hennessey, \& Tighe, 1994), and active processing of information and selection of novel, challenging tasks (Conti, Amabile, \& Pollack, 1995), as well as persistence (Shalley, Zhou, \& Oldham, 2004). Interestingly, research has shown mixed effects of intrinsic motivation on creativity, with some laboratory and field studies indicating a positive relationship, and others suggesting a null relationship (e.g., George, 2007; Shalley et al., 2004).

(p. 515) Grant and Berry (2011) sought to resolve this discrepancy by examining whether the effect of intrinsic motivation on creativity is contingent on prosocial motivation. They proposed that while intrinsic motivation fosters a focus on novel ideas, prosocial motivation is important for encouraging perspective taking about what others find useful (Grant \& Berry, 2011). They found support for these hypotheses across field studies of military officers and water treatment employees, as well as in a laboratory experiment. We hope to see further research build on this evidence to examine other motivational processes that foster a focus on usefulness, complementing the attention to novelty cultivated by intrinsic motivation. Such investigations will further enhance our understanding of the effects of motivation on creativity.

More broadly, we hope to see scholars investigate the impact of motivation on a wider range of dependent variables. Our discussion of creativity aligns with increasing attention of organizational researchers to employee behaviors that go beyond core task requirements: organizational citizenship behaviors such as helping and sportsmanship (e.g., Organ, 1988; Podsakoff, MacKenzie, Paine, \& Bachrach, 2000), proactive behaviors such as voicing suggestions and taking charge to introduce new work methods (Grant \& Parker, 2009; Parker et al., 2010), and counterproductive behaviors such as aggression, theft, and sabotage (Griffin \& Lopez, 2005; Spector \& Fox, 2010). Different motivations may play a key role in shaping which of these behavioral directions employees pursue.

\section{Rewards and Motivation}

Another key direction involves identifying the conditions under which rewards increase motivation. A debate currently exists about whether managers underestimate the power of intrinsic relative to extrinsic rewards for motivating employees (Heath, 1999), or whether there is a discrepancy between what employees say and what they do, such that employees report that extrinsic rewards are relatively unimportant, but the preferences revealed by their behaviors suggest otherwise (Rynes, Gerhart, \& Minette, 2004). Scholars may take steps to resolve this debate by attending not only to the instrumental features of rewards but also to their symbolic features. For example, Mickel and Barron (2008) propose that rewards will be more likely to increase motivation when they are distributed by high-status authority figures, for high performance and accomplishments, and in public ceremonies. 


\section{Work Motivation: Directing, Energizing, and Maintaining Effort (and Research)}

This raises a more general issue with respect to rewards: We believe that lumping all rewards into a common category has obscured the importance of understanding the effects of different types of rewards on motivation. In particular, researchers have focused primarily on pay and financial incentives, giving far less emphasis to more symbolic rewards such as recognition and appreciation, even though these rewards are frequently intended to motivate and can be effective (Stajkovic \& Luthans, 2001; see also Frey, 2007, and Grant \& Gino, 2010). We hope to see scholars build and test theories about the motivational effects of different types of recognition systems.

\section{Conclusion}

Scholars have explored many other issues related to work motivation that fall outside the scope of this chapter. For example, important developments have examined how motivation is shaped by needs and motives (for reviews, see Ambrose \& Kulik, Steers, Mowday, \& Shapiro, 2004), personality traits (e.g., Barrick, Stewart, \& Piotrowski, 2002; Judge \& Ilies, 2002), culture (Erez, 2010), and nonwork factors (George \& Brief, 1996; Kossek \& Misra, 2008; Rothbard, 2001). Furthermore, extensive treatments of the role of self-regulation processes are available elsewhere (Diefendorff \& Chandler, 2010). In addition, some scholars have developed integrative perspectives and models that bring together multiple motivation theories (Locke \& Latham, 2004; Mitchell \& Daniels, Steel \& König, 2006). It remains to be seen whether an integrative model of motivation is desirable, or even possible. Our own view is that given the complexity of psychological, social, and situational influences on motivation, researchers are best advised to develop, test, and elaborate middle-range theories (Weick, 1974 ) that are problem drivendesigned to explain particular phenomena and outcomes, rather than seeking to generalize to all outcomes (Lawrence, 1992). Nevertheless, we hope this chapter is useful in summarizing key trends in the study of work motivation and directing, energizing, and maintaining future research.

\section{References}

Adams, J. S. (1963). Toward an understanding of inequity. Journal of Abnormal and Social Psychology , $67,422-436$.

Adams, J. S. (1965). Inequity in social exchange. In L. Berkowitz (Ed.), Advances in experimental social psychology (Vol. 2, pp. 267-299). New York: Academic Press.

Adler, P. S., \& Chen, C. X. (2009). Beyond intrinsic motivation: On the nature of individual motivation in large-scale collaborative creativity. Social Science Research Network Retrieved August 2, 2011, from https://msbfile03.usc.edu/digitalmeasures/padler/ intellcont/BEYOND\%20INTRINSIC\%20MOTIVATION-1.pdf 
Ajzen, I. (1991). The theory of planned behavior.

Organizational Behavior and Human

Decision Processes , 50, 179-211.

Amabile, T. M. (1988). A model of creativity and innovation in organizations.

Research in

Organizational Behavior , 10,123-167.

Amabile, T. M. (1993). Motivational synergy: Toward new conceptualizations of intrinsic and extrinsic motivation in the workplace.

Human Resource Management Review

$, 3,185-$

201.

Amabile, T.M. (1996). Creativity in context $\quad$. Boulder, CO: Westview Press.

Amabile, T. M., Hennessey, B. A., \& Grossman, B. S. (1986). Social influences on

creativity: The effects of contracted-for reward.

Journal of Personality and Social

Psychology , $50,14-23$.

Amabile, T. M., Hill, K. G., Hennessey, B. A., \& Tighe, E. M. (1994). The Work Preference Inventory: Assessing intrinsic and extrinsic motivational orientations.

Journal of

Personality and Social Psychology , 66, 950-967.

Amabile, T. M., \& Mueller, J. S. (2007). Studying creativity, its processes, and its antecedents: An exploration of the componential theory of creativity. In J. Zhou \& C.

Shalley (Eds.), Handbook of organizational creativity (pp. 31-62). Mahwah, NJ: Erlbaum.

Ambrose, M. L., \& Kulik, C. T. (1999). Old friends, new faces: Motivation in the 1990s.

Journal of Management $\quad, 25,231-292$.

Armitage, C. J., \& Conner, M. (2001). Efficacy of the theory of planned behaviour: A meta-

analytic review. British Journal of Social Psychology ，40,471-499.

Ashford, S. J., Rothbard, N. P., Piderit, S. K., \& Dutton, J. E. (1998). Out on a limb: The role of context and impression management in selling gender-equity issues.

Administrative

Science Quarterly , 43, 23-57.

Bandura, A. (1977). Self-efficacy: Toward a unifying theory of behavioral change.

Psychological Review , 84, 191-215.

Barrick, M. R., Stewart, G. L., \& Piotrowski, M. (2002). Personality and job performance:

Test of the mediating effects of motivation among sales representatives.

Journal of

Applied Psychology , 87, 43-51.

Barsky, A. (2008). Understanding the ethical cost of organizational goal-setting: A review and theory development. Journal of Business Ethics ， 81,63-81.

Berg, J. M., Grant, A. M., \& Johnson, V. (2010). When callings are calling: Crafting work and leisure in pursuit of unanswered occupational callings. Organization Science , 21, 973-994. 
Berg, J. M., Wrzesniewski, A., \& Dutton, J. E. (2010). Perceiving and responding to challenges in job crafting at different ranks: When proactivity requires adaptivity. of Organizational Behavior ， 31, 158-186.

Bierly, P. E., \& Spender, J-C. (1995). Culture and high reliability organizations: The case of the nuclear submarine. Journal of Management , 21,639-656.

Bigley, G. A., \& Roberts K. H. (2001). The incident command system: High-reliability organizing for complex and volatile task environments.

Academy of Management Journal $44,1281-1299$.

Bloom, M. (1999). The performance effects of pay dispersion on individuals and organizations. Academy of Management Journal ， 42, 25-40.

Bloom, M., \& Michel, J. G. (2002). The relationships among organizational context, pay dispersion, and managerial turnover. $\quad$ Academy of Management Journal , 45, 33-42.

Bono, J. E., \& Judge, T. A. (2003). Self-concordance at work: Toward understanding the motivational effects of transformational leaders. Academy of Management Journal , 46, 554-571.

Bunderson, J. S., \& Thompson, J. A. (2009). The call of the wild: Zookeepers, callings, and the double-edged sword of deeply meaningful work. Administrative Science Quarterly , 54, $32-57$.

Campbell, D. J., \& Pritchard, R. (1976). Motivation theory in industrial and organizational psychology. In M. D. Dunnette (Ed.), Handbook of industrial and organizational psychology (pp.63-130). Chicago, IL: Rand McNally.

Campion, M. A., \& McClelland, C. L. (1993). Follow-up and extension of the interdisciplinary costs and benefits of enlarged jobs. Journal of Applied Psychology ， 78 , 339-351.

Chen, G., \& Kanfer, R. (2006). Toward a systems theory of motivated behavior in work teams. Research in Organizational Behavior , 27, 223-267.

Chen, G., Kanfer, R., DeShon, R. P., Mathieu, J. E., \& Kozlowski, S. W. J. (2009). The motivating potential of teams: Test and extension of Chen \& Kanfer's (2006) cross-level model of motivation in teams. Organizational Behavior and Human Decision Processes $110,45-55$.

Chen, M. J., \& Miller, D. (1994). Competitive attack, retaliation and performance: An expectancy-valence framework. Strategic Management Journal ～， 15, 85-102.

Colella, A., Paetzold, R. L., Zardkoohi, A., \& Wesson, M. J. (2007). Exposing pay secrecy. Academy of Management Review , 32,55-71. 
Conti, R., Amabile, T. M., \& Pollack, S. (1995). Enhancing intrinsic motivation, learning, and creativity. Personality and Social Psychology Bulletin $\quad, 21,1107-1116$.

Deci, E. L., Connell, J. P., \& Ryan, R. M. (1989). Self-determination in a work organization. Journal of Applied Psychology , 74, 580-590.

Deci, E. L., Koestner, R., \& Ryan, R. M. (1999). A meta-analytic review of experiments examining the effects of extrinsic rewards on intrinsic motivation.

Psychological Bulletin $125,627-668$.

Diefendorff, J. M., \& Chandler, M. M. (2010). Motivating employees. In S. Zedeck (Ed.), Handbook of industrial and (p.517) organizational psychology (pp.65-135). Washington, DC: American Psychological Association.

Eisenberger, R. (1992). Learned industriousness. Psychological Review ～～ 99 , 248-267.

Elsbach, K. D., \& Hargadon, A. B. (2006). Enhancing creativity through "mindless" work:

A framework of workday design. Organization Science , 17, 470-483.

Erez, M. (2010). Culture and job design. Journal of Organizational Behavior ， 31, 389-400.

Erez, A., \& Isen, A. M. (2002). The influence of positive affect on the components of expectancy motivation. Journal of Applied Psychology ， 87, 1055-1067.

Frey, B. S. (2007). Awards as compensation. European Management Review $\quad$, 4, 6-14.

Fried, Y., \& Ferris, G. R. (1987). The validity of the job characteristics model: A review and meta-analysis. Personnel Psychology , 40, 287-322.

Fried, Y., Levi, A. S., \& Laurence, G. (2008). Motivation and job design in the new world of work. In S. Cartwright and C. L. Cooper (Eds.), The Oxford handbook of personnel psychology (Vol. 24, pp. 586-611). Oxford, England: Oxford University Press.

Gagné, M., \& Deci, E. L. (2005). Self-determination theory and work motivation. Journal of Organizational Behavior ， 26,331-362.

Gagné, M., \& Forest, J. (2008). The study of compensation systems through the lens of self-determination theory: Reconciling 35 years of debate. Canadian Psychology ， 49, 225232.

George, J. M. (2007). Creativity in organizations. Academy of Management Annals $\quad, 1,439$ 477.

George, J. M., \& Brief, A. P. (1996). Motivational agendas in the workplace: The effects of feelings on focus of attention and work motivation. Research in Organizational Behavior $18,75-109$. 


\section{Work Motivation: Directing, Energizing, and Maintaining Effort (and Research)}

Grant, A. M. (2007). Relational job design and the motivation to make a prosocial

difference. Academy of Management Review , 32, 393-417.

Grant, A. M. (2008a). Does intrinsic motivation fuel the prosocial fire? Motivational synergy in predicting persistence, performance, and productivity. Journal of Applied Psychology , 93, 48-58.

Grant, A. M. (2008b). The significance of task significance: Job performance effects, relational mechanisms, and boundary conditions. Journal of Applied Psychology 93, 108124.

Grant, A. M., \& Berry, J. (2011). The necessity of others is the mother of invention: Intrinsic and prosocial motivations, perspective-taking, and creativity. Academy of Management Journal , 54,73-96.

Grant, A. M., Campbell, E. M., Chen, G., Cottone, K., Lapedis, D., \& Lee, K. (2007). Impact and the art of motivation maintenance: The effects of contact with beneficiaries on persistence behavior. Organizational Behavior and Human Decision Processes $, 103,53-$ 67.

Grant, A. M., \& Gino, F. (2010). A little thanks goes a long way: Explaining why gratitude expressions motivate prosocial behavior. Journal of Personality and Social Psychology , 98 .

Grant, A. M., \& Parker, S. K. (2009). Redesigning work design theories: The rise of relational and proactive perspectives. Academy of Management Annals , 3, 317-375.

Grant, A. M., \& Wade-Benzoni, K. (2009). The hot and cool of death awareness at work: Mortality cues, aging, and self-protective and prosocial motivations. Academy of Management Review ， 34,600-622.

Griffin, R. W. (1983). Objective and social sources of information in task redesign: A field experiment. Administrative Science Quarterly ， 28, 184-200.

Griffin, R. W., \& Lopez, Y. P. (2005). 'Bad behavior' in organizations: A review and typology for future research. Journal of Management , 31, 988-1005.

Hackman, J. R., \& Lawler, E. E. (1971). Employee reactions to job characteristics.

Journal of Applied Psychology , $55,259-286$.

Hackman, J. R., \& Oldham, G. R. (1976). Motivation through the design of work: Test of a theory. Organizational Behavior and Human Performance , 16, 250-279.

Hackman, J. R., \& Oldham, G. R. (1980). Work redesign . Reading, MA: Addison-Wesley. Harder, J. W. (1991). Equity theory versus expectancy theory: The case of major league baseball free agents. Journal of Applied Psychology , 76, 458-464. 
Heath, C. (1999). On the social psychology of agency relationships: Lay theories of motivation overemphasize extrinsic incentives. Organizational Behavior and Human

Decision Processes , 78, 25-62.

Heath, C., \& Sitkin, S. (2001). Big-B versus Big-O: What is organizational about organizational behavior? Journal of Organizational Behavior , 22, 43-58.

Hennessey, B. A., Amabile, T. M., \& Martinage, M. (1989). Immunizing children against the negative effects of reward. Contemporary Educational Psychology , 14, 212-227.

Herzberg, F. (1959). The motivation to work . New York: Wiley.

Hofmann, D. A., \& Stetzer, A. (1998). The role of safety climate and communication in accident interpretation: Implications for learning from negative events. Academy of Management Journal ，41,644-657.

Hornung, S., Rousseau, D. M., Glaser, J., Angerer, P., \& Weigl, M. (2010). Beyond top-down and bottom-up work redesign: Customizing job content through idiosyncratic deals. Journal of Organizational Behavior $\quad, 31,187-215$.

Huseman, R. C., Hatfield, J. D., \& Miles, E. W. (1987). A new perspective on The equity sensitivity construct. Academy of Management Review , 12, 222-234.

Judge, T. A., \& llies, R. (2002). Relationship of personality to performance motivation: A meta-analytic review. Journal of Applied Psychology , 87, 797-807.

Kanfer, R. (1990). Motivation theory and industrial and organizational psychology. In M.
D. Dunnette (Ed.),
Handbook of industrial and organizational psychology
(Vol. 1, 2nd ed., pp. 75-130). Palo Alto, CA: Consulting Psychologists Press.

Kanfer, R., \& Ackerman, P. L. (2004). Aging, adult development, and work motivation.

Academy of Management Review ～, 29, 440-458.

Kanfer, R., Chen, G., \& Pritchard, R. D. (Eds.). (2008). Work motivation: Past, present, and

future . New York: Taylor and Francis Group.

Katzell, R. A., \& Thompson, D. E. (1990). Work motivation: Theory and practice.

American

Psychologist , $45,144-153$.

Koestner, R., \& Losier, G. F. (2002). Distinguishing three ways of being highly motivated: A closer look at introjection, identification, and intrinsic motivation. In R. Koestner, G. F. Losier, E. L. Deci, \& R. M. Ryan (Eds.), Handbook of self-determination research (pp. 101121). Rochester, NY: University of Rochester Press.

Kossek, E., \& Misra, K. (2008). Non-work influences on work motivation. In R. Kanfer, G. Chen, \& R. Pritchard (Eds.), $\quad$ (p. 518) Work motivation: Past, present, and future (pp. 471500). New York: Taylor and Francis Group. 


\section{Work Motivation: Directing, Energizing, and Maintaining Effort (and Research)}

Kramer, R. (1999). Trust and distrust in organizations: Emerging perspectives, enduring questions. Annual Review of Psychology ，50,569-598.

Latham, G. P., Erez, M., \& Locke, E. A. (1988). Resolving scientific disputes by the joint design of crucial experiments by the antagonists: Application to the Erez-Latham dispute regarding participation in goal setting. Journal of Applied Psychology ， 73, 753-772.

Latham, G. P., \& Locke, E. A. (2009). Science and ethics: What should count as evidence against the use of goal setting? Academy of Management Perspectives , 23, 88-91.

Latham, G. P., \& Pinder, C. C. (2005). Work motivation theory and research at the dawn of the twenty-first century. Annual Review of Psychology ，56, 495-516.

Latham, G. P., \& Saari, L. M. (1982). The importance of union acceptance for productivity improvement through goal setting. Personnel Psychology , 35, 781-787.

Lawrence, P. R. (1992). The challenge of problem-oriented research. Journal of Management Inquiry $\quad, 1,139-142$.

Leana, C., Appelbaum, E., \& Shevchuk, I. (2009). Work process and quality of care in early childhood education: The role of job crafting. Academy of Management Journal ，52 , 1169-1192.

Locke, E. A., \& Latham, G. P. (1990). $\quad$ A theory of goal-setting and task performance Englewood Cliffs, NJ: Prentice-Hall.

Locke, E. A., \& Latham, G. P. (2002). Building a practically useful theory of goal setting and task motivation: A 35-year odyssey. American Psychologist ， 57, 705-717.

Locke, E. A., \& Latham, G. P. (2004). What should we do about motivation theory? Six recommendations for the twenty-first century. Academy of Management Review ～, 29, 388403.

Locke, E. A., \& Latham, G. P. (2009). Has goal setting gone wild, or have its attackers abandoned good scholarship? Academy of Management Perspectives ， 23, 17-23.

Locke, E. A., Motowidlo, S. J., \& Bobko, P. (1986). Using self-efficacy theory to resolve the conflict between goal-setting theory and expectancy theory in organizational behavior and industrial/organizational psychology. Journal of Social and Clinical Psychology , 4, 328-338.

Mastrofski, S. D., Ritti, R. R., \& Snipes, J. B. (1994). Expectancy theory and police productivity in DUI enforcement. Law and Society Review ， 28, 113-148. McClelland, D. C. (1961). The achieving society $\quad$. New York: Van Nostrom Reinhold. 
Messersmith, J. G., Guthrie, J. P., Ji, Y.-Y., \& Lee, J.-Y. (2011). Executive turnover: The influence of dispersion and other pay system characteristics. Journal of Applied

Psychology , 96, 457-469.

Mickel, A. E., \& Barron, L. A. (2008). Getting "more bang for the buck": Symbolic value of monetary rewards in organizations. Journal of Management Inquiry ， 17, 329-338.

Miles, E. W., Hatfield, J. D., \& Huseman, R. C. (1989). The equity sensitivity construct:

Potential implications for worker performance. Journal of Management ， 15, 581-588.

Mitchell, T. R., \& Biglan, A. (1971). Instrumentality theories: Current uses in psychology.

Psychological Bulletin $\quad, 76,432-454$.

Mitchell, T. R., \& Daniels, D. (2003). Motivation. In W. Borman, D. Ilgen, \& R. Klimoski

(Eds.), Handbook of psychology. Vol. 12: Industrial/organizational psychology

(pp. 225254). New York: Wiley.

Morgeson, F. P., \& Campion, M. A. (2002). Avoiding tradeoffs when redesigning work:

Evidence from a longitudinal quasi-experiment. Personnel Psychology ， 55, 589-612.

Morgeson, F. P., \& Humphrey, S. E. (2008). Job and team design: Toward a more integrative conceptualization of work design. In J. Martocchio (Ed.), Research in personnel and human resource management (Vol. 27, pp. 39-92). Bingley, England: Emerald Group Publishing Limited.

Nicholson, N. (1984). A theory of work role transitions. Administrative Science Quarterly $29,172-191$.

Oldham, G. R., \& Hackman, J. R. (2010). Not what it was and not what it will be: The future of job design research. Journal of Organizational Behavior J , 31, 463-479.

Ordoñez, L. D., Schweitzer, M. E., Galinsky, A. D. \& Bazerman, M. H. (2009a). Goals gone wild: The systematic side effects of overprescribing goal setting. Academy of Management Perspectives ， 23,6-22.

Ordoñez, L. D., Schweitzer, M. E., Galinsky, A. D., \& Bazerman, M. H. (2009b). On good scholarship, goal setting, and scholars gone wild.

Academy of Management Perspectives $23,82-87$.

Organ, D. W. (1988). Organizational citizenship behavior: The good soldier syndrome Lexington, MA: Lexington Books.

Osterloh, M., \& Frey, B. (2000). Motivation, knowledge transfer and organizational form. Organization Science $\quad, 11,538-550$.

Parker, S. K., Bindl, U. K., \& Strauss, K. (2010). Making things happen: A model of proactive motivation. Journal of Management , 36, 827-856. 
Parker, S. K., \& Ohly, S. (2008). Designing motivating jobs. In R. Kanfer, G. Chen, \& R.

Pritchard (Eds.), Work motivation: Past, present, and future $\quad$ (pp. 233-284). New York:

LEA/Psychology Press.

Parker, S. K., Wall, T. D., \& Cordery, J. L. (2001). Future work design research and practice: Towards an elaborated model of work design. Journal of Occupational and

Organizational Psychology $\quad, 74,413-440$.

Parker, S. K., Wall, T. D., \& Jackson, P. R. (1997). 'That's not my job': Developing flexible employee work orientations. Academy of Management Journal ～， 40,899-929.

Penner, L. A., Dovidio, J. F., Piliavin, J. A., \& Schroeder, D. A. (2005). Prosocial behavior:

Multilevel perspectives. Annual Review of Psychology ， 56, 365-392.

Perugini, M., \& Bagozzi, R. P. (2001). The role of desires and anticipated emotions in goaldirected behaviours: Broadening and deepening the theory of planned behavior. Journal of Social Psychology , 40, 79-98.

Pfeffer, J., \& Langton, N. (1993). The effect of wage dispersion on satisfaction, productivity, and working collaboratively: Evidence from college and university faculty. Administrative Science Quarterly ，38, 382-407.

Podsakoff, P. M., MacKenzie, S. B., Paine, J. B., \& Bachrach, D. G. (2000). Organizational citizenship behaviors: A critical review of the theoretical and empirical literature and suggestions for future research. Journal of Management ，26,513-563.

Porter, L. W., \& Lawler, E. E., III. (1968). Managerial attitudes and performance Homewood, IL: Dorsey Press.

Roberts, B. W., Edmonds, G., \& Grijalva, E. (2010). It is developmental me, not generation me: Developmental changes are more important than generational changes in narcissism —comment on Trzesniewski \& Donnellan (2010). Perspectives on Psychological Science $5,97-102$.

Rothbard, N. P. (2001). Enriching or depleting? The dynamics of engagement in work and family roles. Administrative Science Quarterly , 46, 655-684.

(p. 519) Rousseau, D. M., Ho, V. T., \& Greenberg, J. (2006). I-deals: Idiosyncratic terms in employment relationships. Academy of Management Review ～，31, 977-994.

Ryan, R. M., \& Deci, E. L. (2000). Self-determination theory and the facilitation of intrinsic motivation, social development, and well-being. American Psychologist $\quad$, $55,68-$ 78.

Rynes, S. L., Gerhart, B., \& Minette, K. A. (2004). The importance of pay in employee motivation: Discrepancies between what people say and what they do.

Human Resource Management , $43,381-394$. 

Research)

Salancik, G. R., \& Pfeffer, J. (1978). A social information processing approach to job

attitudes and task design. Administrative Science Quarterly ， 23, 224-253.

Schweitzer, M. E., Ordoñez, L., \& Douma, B. (2004). Goal setting as a motivator of unethical behavior. Academy of Management Journal ， 47, 422-432.

Seo, M., Barrett, L. F., \& Bartunek, J. M. (2004). The role of affective experience in work motivation. Academy of Management Review , 29, 423-439.

Shalley, C. E., Zhou, J., \& Oldham, G. R. (2004). The effects of personal and contextual characteristics on creativity: Where should we go from here? Journal of Management , 30 , 933-958.

Shamir, B. (1990). Calculations, values, and identities: The sources of collectivistic work motivation. Human Relations , 43, 313-332.

Shamir, B. (1991). Meaning, self and motivation in organizations.

Organization Studies $12,405-424$.

Siegel, P. A., \& Hambrick, D. C. (2005). Pay disparities within top management groups: Evidence of harmful effects on performance of high-technology firms. Organization Science , 16, 259-274.

Spector, P. E., \& Fox, S. (2010). Theorizing about the deviant citizen: An attributional explanation of the interplay of organizational citizenship and counterproductive work behavior. Human Resource Management Review ，20,132-143.

Stajkovic, A. D., \& Luthans, F. (2001). Differential effects of incentive motivators on work performance. Academy of Management Journal , 44, 580-590.

Staw, B. M. (1984). Organizational behavior: A review and reformulation of the field's outcome variables. Annual review of Psychology , 35, 627-666.

Steel, P., \& König, C. J. (2006). Integrating theories of motivation. Academy of Management Review ， 31, 889-913.

Steers, R., Mowday, R., \& Shapiro, D. (2004). The future of work motivation theory. Academy of Management Review , $29,379-387$.

Trist, E. L., \& Bamforth, K. M. (1951). Some social and psychological consequences of the longwall method of coal-getting. Human Relations , 4, 3-38.

Trzesniewski, K. H., \& Donnellan, M. B. (2010). Rethinking "Generation Me": A study of cohort effects from 1976-2006. Perspectives on Psychological Science $\quad$, 5, 58-75.

Turner, A. N., \& Lawrence, P. R. (1965). $\quad$ Industrial jobs and the worker $\quad$. Boston, MA: Harvard University Press. 
Twenge, J. M., Campbell, S. M., Hoffman, B. J., \& Lance, C. E. (2010). Generational

differences in work values: Leisure and extrinsic values increasing, social and intrinsic

values decreasing. Journal of Management $\quad, 36,1117-1142$.

Van Eerde, W., \& Thierry, H. (1996). Vroom's expectancy models and work-related

criteria: A meta-analysis. Journal of Applied Psychology ， 81, 575-586.

Vogus, T. J., \& Welbourne, T. M. (2003). Structuring for high reliability: HR practices and mindful processes in reliability-seeking organizations.

Journal of Organizational Behavior

$24,877-903$.

Vroom, V. H. (1964). Work and motivation . New York: Wiley.

Waller, M. J., \& Roberts, K. H. 2003. High reliability and organizational behavior: Finally

the twain must meet. Journal of Organizational Behavior , 24,813-814.

Weick, K. E. (1966). The concept of equity in the perception of pay.

Administrative

Science Quarterly ，11,414-439.

Weick, K. E. (1974). Middle range theories of social systems.

Behavioral Science $\quad, 19,357-$

367.

Weick, K. E. (1979). The social psychology of organizing (2nd ed.). Reading, MA: Addison-

Wesley.

Weick, K. E., \& Roberts, K. (1993). Collective mind in organizations: Heedful interrelating

on flight decks. Administrative Science Quarterly ，38, 357-381.

Weick, K. E., Sutcliffe, K. M., \& Obstfeld, D. (1999). Organizing for high reliability:

Processes of collective mindfulness. Research in Organizational Behavior

$, 21,81-123$.

Weick, K. E., Sutcliffe, K. M., \& Obstfeld, D. (2005). Organizing and the process of

sensemaking. Organization Science ，16,409-421.

Wilson, T. D., \& Gilbert, D. T. (2005). Affective forecasting: Knowing what to want.

Current Directions in Psychological Science ， 14, 131-134.

Wong, C., \& Campion, M. A. (1991). Development and test of a task level model of

motivational job design. Journal of Applied Psychology , 76, 825-837.

Wrzesniewski, A., \& Dutton, J. E. (2001). Crafting a job: Revisioning employees as active

crafters of their work. Academy of Management Review ～, 26, 179-201.

Wrzesniewski, A., McCauley, C. R., Rozin, P., \& Schwartz, B. (1997). Jobs, careers, and

callings: People's relations to their work. Journal of Research in Personality

$, 31,21-33$.

Xie, J. L., \& Johns, G. (1995). Job scope and stress: Can job scope be too high?

Academy of

Management Journal , $38,1288-1309$.

Page 28 of 29

PRINTED FROM OXFORD HANDBOOKS ONLINE (www.oxfordhandbooks.com). (c) Oxford University Press, 2015. All Rights

Reserved. Under the terms of the licence agreement, an individual user may print out a PDF of a single chapter of a title in

Oxford Handbooks Online for personal use (for details see Privacy Policy). 

Research)

Zalesny, M. D., \& Ford, J. K. (1990). Extending the social information processing perspective: New links to attitudes, behaviors, and perceptions.

Organizational Behavior and Human Decision Processes , $47,205-246$.

Zohar, D., \& Luria, G. (2003) . Organizational meta-scripts as a source of high reliability:

The case of an army armored brigade. Journal of Organizational Behavior , 24, 837-859.

Notes:

(1.) More recent work suggests that the psychological processes underlying the model can be further illuminated by including desires as micromediators of the effects of beliefs on intentions (Perugini \& Bagozzi, 2001).

(2.) Some scholars have challenged the theoretical and empirical appropriateness of lumping self-efficacy and perceived behavioral control together. The central distinction lies in that self-efficacy describes judgments of one's internal capability to perform a behavior, whereas perceived behavioral control also incorporates judgments of whether external forces may limit the controllability of the behavior (see Armitage \& Conner, 2001, p. 476), which suggests that perceived behavioral control and expectancy beliefs share greater similarity with each other than they do with self-efficacy.

\section{Adam M. Grant}

Adam M. Grant, Management Department, The Wharton School, University of Pennsylvania, Philadelphia, Pennsylvania

\section{Jihae Shin}

Jihae Shin, The Wharton School, University of Pennsylvania.

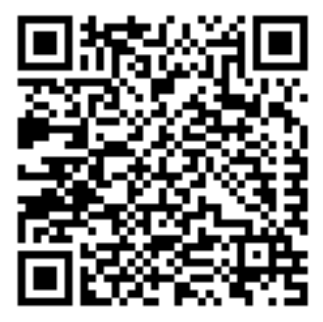

